\title{
ESTONIAN GEMINATE PLOSIVES: SOME DURATIONAL CHARACTERISTICS
}

\author{
Liis Ermus \\ Institute of the Estonian Language
}

\begin{abstract}
Consonants in Estonian occur in three quantity degrees: short, long, and overlong. Plosives have also been described as lenis and fortis. Long and fortis correspond to geminate. As single plosives have been described acoustically several times, only overall durations of geminates have been reported. The present study examines durational patterns of geminate plosives in Estonian and their relations to the same patterns in single plosives. Influences of articulation place, quantity, syllable structure, and speech style on overall duration, burst duration, and voiced transition were sought. The biggest differences in duration occurred due to quantity degree. Some influence of syllable structure occurred, similar to previous findings. Patterns were mostly similar to those in singleton plosives, although there were some differences in voicing. Almost no difference compared to singletons with respect to burst phase duration was found.
\end{abstract}

Keywords: Estonian, geminates, plosives, duration, connected speech, acoustic phonetics

DOI: https://doi.org/10.12697/jeful.2019.10.1.02

\section{Introduction}

\subsection{Geminate plosives}

Geminate is a long consonant that can be analysed as a sequence of two same consonants (Ladefoged and Johnson 2010: 251). Opposition of single and geminate or short and long is used in quantity languages. In most quantity languages geminates can occur only in word-medial position but languages consisting word-final and word-initial also exist, for example, in Tashlhiyt Berber (Ridouane 2014), Malay (Abramson 1986 and Ridouane and Hallé 2017), and Swiss German (Kraehenmann 2001). Obstruents are most often geminated, while glides most rarely (for overview see Hansen and Myers 2017). 
The most important feature distinguishing singletons and plosives is the duration. Geminates have longer durations, approximately 1.5-3 times that of singletons, according to Ladefoged and Maddieson (1996: 92). An important additional characteristic is the length or quality adjacent vowels (Idemaru and Guion 2008).

Plosives are characterised by distinguishable phases in pronunciation: implosion - forming the closure, occlusion - holding the closure, explosion or burst - release of the closure (Ladefoged 2001). Burst phase is described with voice onset time (VOT) - duration between the beginning of the burst and appearance of voicing or harmonic vibration. Duration of the VOT phase is influenced primarily by articulation place (volume of the cavity behind and in front of the point of constriction), mobility of the articulator and articulation force (Cho and Ladefoged 1999).

In gemination, the phasal structure of plosive persists (there is just one closure and one burst during the geminate). The closure lengthens the most. Differences in burst phase may include longer duration and higher intensity that manifests as aspiration (Cho et al. 2002, 2019). Longer articulation time is accompanied by larger contact areas and more density between articulators. Probably that is the foundation for the lenis-fortis contrast based on articulatory force (Ladefoged and Maddieson 1996). It may be used interchangeably with quantity or voicing contrast. This system has been used to characterise Korean (Lee 1993), German (Kuzla and Ernestus 2011), and Estonian (Eek and Meister 1996), among others. Still, the concept has been shown to be rather abstract, with various possible features and outcomes (for discussion, see Butcher 2004).

\subsection{Plosives in Estonian}

Estonian has three plosives - bilabial /p/, alveolar /t/, and velar $/ \mathrm{k} /$. No voicing or aspiration contrast occurs; ternary quantity system is used instead. The first quantity degree $(\mathrm{Q} 1)$ corresponds to the short or the single sound and the second $(\mathrm{Q} 2)$ and the third quantity degree (Q3) correspond to the long and overlong geminate sound. The quan-

tity system includes all sounds of speech. Sonorant consonants are in a mutual exclusion relation with vowels: only single sonorants can occur after long vowels, and vice versa. Obstruents, on the other hand, 
can occur long after both short and long vowels (Asu and Teras 2009: 370-371 and Asu et al. 2016: 67-68). All consonants can be geminates, but there is a restriction in that only consonants occurring on the border of two syllables in the voiced environment can be analysed as geminate (Asu and Teras 2009: 367-368). Fortis and lenis opposition has been used to describe plosives (Eek and Meister 1996 and Asu et al. 2016: 66).

Türk (2018) presented average durations of Estonian intervocalic consonants in connected speech in three quantities. Durations of geminate plosives were as follows: / $/ 112 \mathrm{~ms}$ in Q2 and $154 \mathrm{~ms}$ in Q3; $/ \mathrm{p} / 134 \mathrm{~ms}$ in Q2 and $159 \mathrm{~ms}$ in Q3; /t/ $116 \mathrm{~ms}$ in Q2 and $145 \mathrm{~ms}$ in Q3. Ariste (1933a) measured durations of intervocalic plosives in single words in different syllable structures. Durations were between 140-280 ms in Q2 for all plosives and 150-370 ms in Q3 (the most common durations were reported), while Q3 durations after long vowels were closer to Q2 durations. Lehiste (1997) also measured consonant durations in different syllable structures in di- and trisyllabic words (all plosives pooled into one word type). Average durations were between 100 and $180 \mathrm{~ms}$ in Q2 (durations were shorter in longer words) and between 156 and $301 \mathrm{~ms}$ in Q3. In Q3 words, plosives were shorter after long vowels and diphthongs, the same pattern as found by Ariste.

Reduction in Estonian has mostly been studied in short/single plosives. Voicing of short plosives has been noted in various speech styles: single words (Ariste 1933b), sentences (Suomi and Meister 2012), news texts (Ermus and Mihkla 2019), and spontaneous speech (Ermus 2017). Voicing has been present from a few percent of the occurrences to over half the analysed tokens. The velar plosive $/ \mathrm{k} /$ has been found to have the largest amount of voicing and, as well, reduction of the burst phase. Voicing in geminates/fortis plosives in intervocalic position was studied by Ariste (1933a). He measured durations of plosive tokens and voicing by tenths of the overall duration. He found that voicing in the beginning of the closure usually was between 10 and 20 percent of the duration of the token in both single words and in full sentences.

According to the preceding information, I posed following hypotheses: 
H1: Patterns in pronunciation of geminate plosives are similar to those of singleton plosives.

H2: Duration differences between Q2 and Q3 are statistically significant.

H3: Syllable structure influences the duration of the plosive and the duration of the voiced transition.

H4: There is a significant difference between burst durations between singleton and geminate plosives.

\section{Material and method}

The material for the study consisted of spoken data from 19 speakers in total: (a) speech samples of five male and seven female speakers from the Phonetic Corpus of Estonian Spontaneous Speech (Lippus 2018) and (b) speech samples of four male and three female speakers from the speech synthesis corpus of Institute of the Estonian Language (Piits 2016). The material from Lippus (2018) consists of conference speeches and lectures. The material from Piits (2016) consists of read sentences from news texts and literature. Sound files in both corpora are annotated in the acoustics program Praat (Boersma and Weenink 2019) using SAMPA transcription (Wells 2015). The material in Lippus (2018) is annotated manually; material in Piits (2018) is annotated on the segmental level using the automatic annotation program (Kisler et al. 2017).

I manually annotated the voiced and voiceless parts of the closure phase and the burst phase. Every geminate was taken as one token. Voiced part was marked from the beginning of closure (marked by disappearance of upper formants) to the disappearance of pitch. Burst was marked between the beginning of noise and beginning of first harmonic vibration. An example of the annotation is presented in Figure 1. 


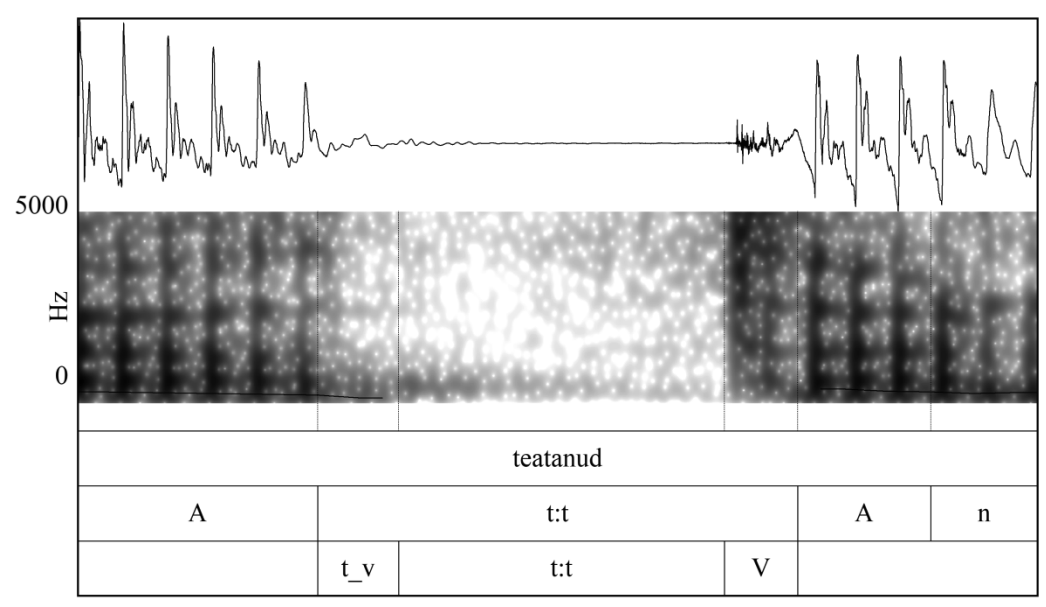

Figure 1. Praat textgrid annotation of the Q3 word 'teatanud' (announced) in SAMPA transcription. ' $V$ 'denotes the burst phase.

I observed the durations of intervocalic plosive tokens in Q2 and Q3 that were positioned on the boundary of the first and second syllable.

The data set (Table 1) contained 1795 tokens in total: 511 tokens of $/ \mathrm{k} /, 374$ tokens of $/ \mathrm{p} /$, and 955 tokens of $/ \mathrm{t} /$. Majority of tokens of $/ \mathrm{k} /$ and $/ \mathrm{t} /$ were in Q3 (65\% and 70\% respectively).

Table 1. Distribution of tokens in the data set.

\begin{tabular}{llll}
\hline Plosive & Q2 & Q3 & Total \\
\hline$/ \mathrm{k} /$ & 177 & 334 & 511 \\
$/ \mathrm{p} /$ & 205 & 169 & 374 \\
$/ \mathrm{t} /$ & 283 & 627 & 910 \\
\hline
\end{tabular}

Statistical computations were conducted in R (R Core Team 2019) using the lme4 package (Bates et al. 2015). Linear mixed (lmer) models were fitted for the overall duration, for the duration of the burst phase, and for the duration of voiced transition at the beginning plosive token. A generalised mixed model (glmer) was fitted for the occurrence of partly voiced closure. Altogether 16 models were fitted (four for every feature - one for all plosives together and one for each plosive separately). 
Fixed variables were the quantity of the word (levels Q2, Q3; reference level Q2), allophone (levels voiceless, partly voiced; reference level voiceless), syllable structure (levels VCV, VVCV; reference level VCV), and reading style (levels read, spoken; reference level spoken). Additionally, for duration models for all plosives together fixed variable plosive (levels $/ \mathrm{p} /, / \mathrm{t} /, / \mathrm{k} /$, reference level $/ \mathrm{k} /$ ), and in the models for burst and voiced transition, also the duration of the plosive segment. The speaker and the word were included as random intercepts. Log-normalised durations were used in the statistical modelling.

\section{Results}

\subsection{Overall durations}

Durational variation is presented in Table 2 and Figure 2.

Table 2. Mean durations of plosives in ms (median durations provided in parentheses).

\begin{tabular}{lccc}
\hline Plosive & Overall duration & Q2 & Q3 \\
\hline$/ \mathrm{k} /$ & $129(122)$ & $119(114)$ & $139(133)$ \\
$/ \mathrm{p} /$ & $140(130)$ & $122(111)$ & $156(149)$ \\
$/ \mathrm{t} /$ & $134(126)$ & $119(114)$ & $143(135)$ \\
\hline
\end{tabular}

The plosive / $\mathrm{p} /$ had the longest mean duration in overall durations and also in both quantity degrees. One-way ANOVA was used for evaluating duration differences. Differences in durations between the plosives were significant $[F(2,1837)=6.58, p<.001]$. A Tukey Honestly Significant Difference post-hoc test (TukeyHSD) confirmed the significant difference between the durations of $/ \mathrm{k} /$ and $/ \mathrm{p} /(p<.001)$, but pairs $/ \mathrm{k} /-\mathrm{t} / \mathrm{(} p=.076)$ and $/ \mathrm{p} /-\mathrm{t} /(p=.094)$ did not differ from each other significantly.

Durations of the tokens in Q2 were statistically different $[F(2,662)=6.29, p=.002]$; TukeyHSD confirmed the differences between $/ \mathrm{k} /$ and $/ \mathrm{p} /(p=.003)$ and between $/ \mathrm{p} /$ and $/ \mathrm{t} /(p=.014)$. Durations of the tokens in Q3 were also statistically different $[F(2,1172)=6.29, p=.002]$; TukeyHSD confirmed the differences between $/ \mathrm{p} /$ and other plosives ( $p<.001$ in both cases). 

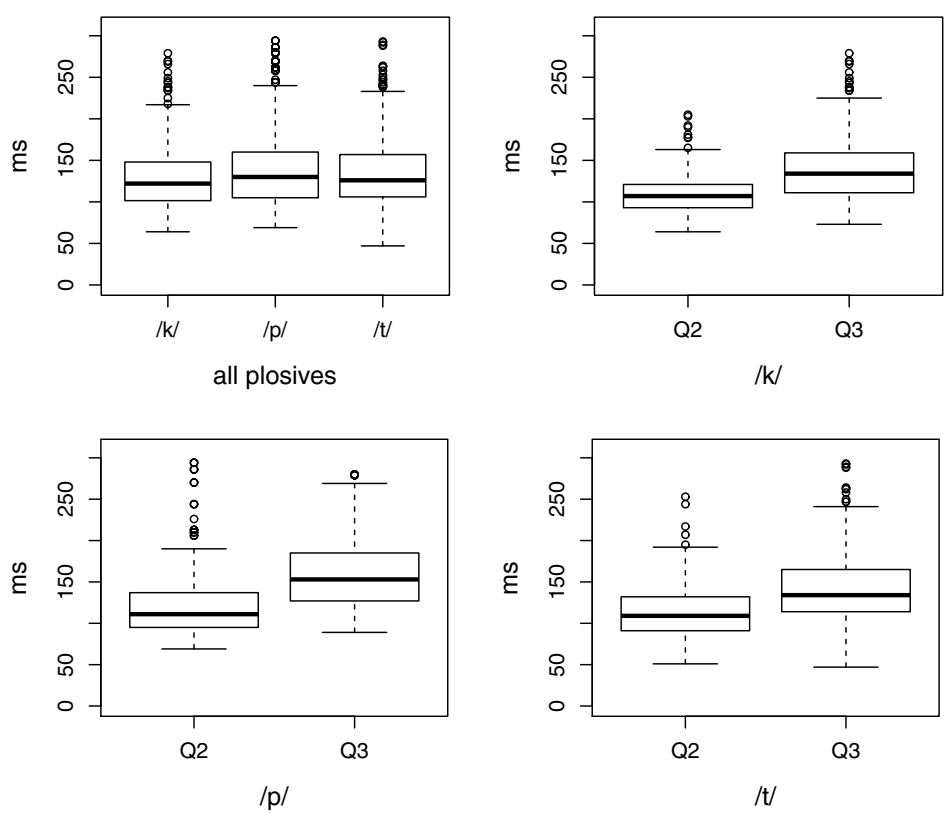

Figure 2. Overall durations.

The difference in mean durations between Q2 and Q3 was at least $20 \mathrm{~ms}$ in all plosives. Differences were statistically significant for all plosives: $/ \mathrm{k} / F(1,509)=87.14, p<.001, / \mathrm{p} / F(1,372)=88.92, p<.001$, $/ \mathrm{t} / F(1,953)=130.7, p<.001$.

Differences between two syllable structures were significant $[F(1,1295)=9.4, p=.002)$. Taking plosives separately, only $/ \mathrm{k} /$ showed a significant difference $[F(1,325)=4.58, p=.033)$.

In the overall duration model, the significant factors were the plosive, quantity, allophone, and syllable structure. The duration of $/ \mathrm{p} /$ was more likely to be longer than that of $/ \mathrm{k} /$ (the reference level) $(p<.001)$. Segments in Q3 were significantly longer than those in Q2 $(p<.001)$. Segments after long vowels were shorter $(p<.001)$. Partly voiced allophones were significantly shorter than voiceless ones $(p=.005)$. Quantity was the most important factor regarding the duration also in models fitted separately for each plosive ( $p<.001$ in all models). Syllable structure showed an effect on the duration of all plosives with shorter durations after long vowels and diphthongs $(p<.001 \mathrm{for} / \mathrm{k} /$ and 
$/ \mathrm{t} /, p=.013$ for $/ \mathrm{p} /)$. Allophone was significant for $/ \mathrm{k} /(p=.020)$ and $/ \mathrm{t} /$ $(p=.008)$ but not for $/ \mathrm{p} /(p=.863)$. Speech style was not significant.

\subsection{Burst phase}

The biggest difference in burst durations was drawn on the plosive (see Table 3 and Figure 3). The mean duration of the burst of $/ \mathrm{k} /$ was around $10 \mathrm{~ms}$ longer than the burst of $/ \mathrm{p} /$ or $/ \mathrm{t} /$. Mean duration of the burst of $/ \mathrm{k} /$ was $26 \mathrm{~ms}$. Bursts of $/ \mathrm{p} /$ and $/ \mathrm{t} / \mathrm{had}$ burst durations under $20 \mathrm{~ms}$. They were the same in Q2 and few milliseconds apart in Q3, with/p/ having the shorter burst.

Table 3. Mean burst durations in ms (median durations given in parentheses).

\begin{tabular}{lccc}
\hline Plosive & Burst duration & Q2 & Q3 \\
\hline$/ \mathrm{k} /$ & $26(25)$ & $26(25)$ & $26(25)$ \\
$/ \mathrm{p} /$ & $16(15)$ & $17(15)$ & $15(14)$ \\
$/ \mathrm{t} /$ & $18(17)$ & $17(17)$ & $18(17)$ \\
\hline
\end{tabular}
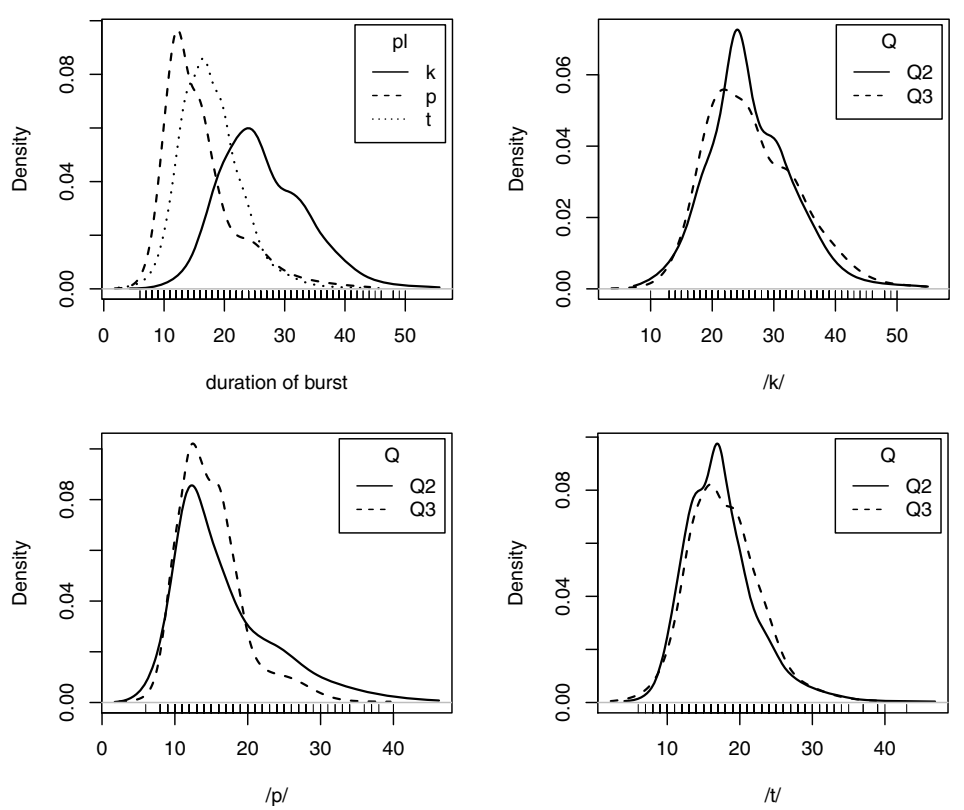

Figure 3. Density plots of burst durations. 
One-way ANOVA found significant difference between burst durations of the plosives $[F(2,1837)=412.75, p<.001]$. TukeyHSD confirmed the differences ( $p<.001$ in all comparisons). Difference by quantity was significant only for $/ \mathrm{p} /[F(1,372)=5.67, p=.020]$ but not for $/ \mathrm{k} /$ and $/ \mathrm{t} /(p>.200)$.

From the models of burst durations, it appeared that the most important factors were the plosive and overall duration of segment. The plosives $/ \mathrm{p} /$ and $/ \mathrm{t} /$ had shorter bursts than $/ \mathrm{k} /(p<.001)$. Segments with longer durations were more likely to have longer bursts $(p<.001)$. The factor Q3, on the other hand, shortened the duration of the burst $(p=.002)$. In separate models for each plosive, influence of duration of the token on the burst duration was stronger on $/ \mathrm{k} /$ and $/ \mathrm{t} /(p<.001)$ and weaker on $/ \mathrm{p} /(p=.016)$. Influence of quantity was somewhat important on $/ \mathrm{k} /$ and $/ \mathrm{p} /$ with shorter burst durations of segments in Q3 (/k/ $p=.046, / \mathrm{p} / p=.038)$. Speech style, allophone, and syllable structure all had no influence on the burst duration.

\subsection{Voiced transition at the beginning of the closure}

For all of the plosives, partly voiced tokens were the majority (Figure 4). The plosive $/ \mathrm{k} /$ had the largest number of voiceless tokens, almost $40 \%$, and $/ \mathrm{p} /$ the biggest amount, over $80 \%$, of partly-voiced tokens.

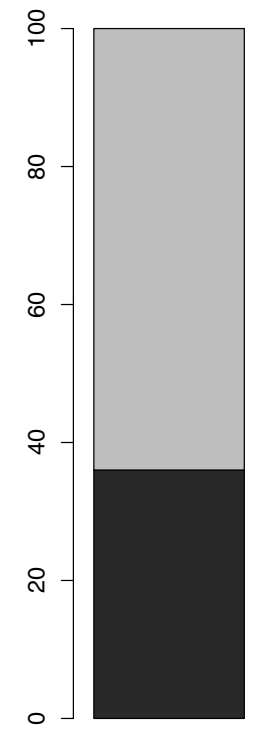

$/ \mathrm{k} /$

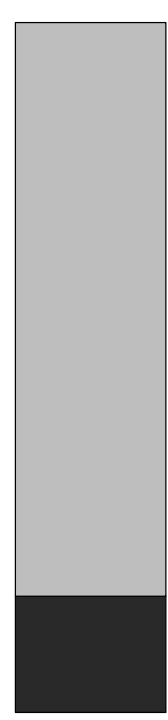

$/ \mathrm{p} /$

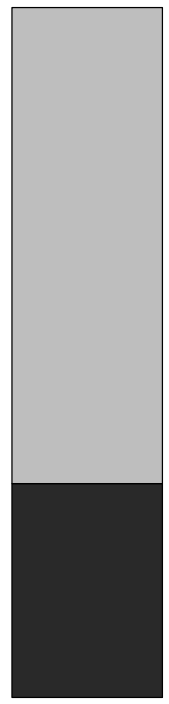

/t/

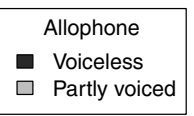

$\square$ Partly voiced

Figure 4. Amount of partly voiced tokens by plosive. 
I fitted the glmer model for finding important factors influencing the occurrence of voiced transition. The plosive $/ \mathrm{p}$ / was significantly more often voiced than $/ \mathrm{k} /$ or $/ \mathrm{t} /(p<.001)$. Tokens with longer durations were less often voiced $(p<.004)$. Tokens after long vowels were less often voiced $(p=.005)$. Quantity degree and speech style did not show any influence.

Table 4. Mean durations of voiced transitions in ms (median durations given in parentheses).

\begin{tabular}{lccc}
\hline Plosive & Overall & Q2 & Q3 \\
\hline$/ \mathrm{k} /$ & $18(16)$ & $18(17)$ & $17(16)$ \\
$/ \mathrm{p} /$ & $25(25)$ & $26(26)$ & $24(24)$ \\
$/ \mathrm{t} /$ & $21(20)$ & $21(19)$ & $21(20)$ \\
\hline
\end{tabular}

Duration of voiced transition was heterogeneous. Mean durations of the voiced part were $18 \mathrm{~ms}$ for $/ \mathrm{k} /, 25 \mathrm{~ms}$ for $/ \mathrm{p} /$, and $21 \mathrm{~ms}$ for $/ \mathrm{t} /$ (Table 4). Durations of transition between plosives were significantly different $[F(2,1294)=74.28, p<.001]$. TukeyHSD confirmed differences between all plosives $(p<.001)$. As seen from Figure 5 , most of the transitions were between 10 and $30 \mathrm{~ms}$. A vast majority of voiced transitions in tokens of $/ \mathrm{k} /$ were less than $20 \mathrm{~ms}$; durations were more evenly distributed for $/ \mathrm{p} /$ and $/ \mathrm{t} /$. There were sporadic very long transitions in all plosives as well. Patterns in Q2 and Q3 were very similar. ANOVA did not find significant differences between quantity degrees for any of the plosives ( $p>.100$ in all cases).

In the models of duration of the voiced transition, significant factors were the plosive, the duration of the segment, and the quantity. The duration of voicing increased with the duration of the token $(p<.001)$ and decreased when the token was in Q3 $(p=.010)$. Both $/ \mathrm{p} /$ and $/ \mathrm{t} / \mathrm{had}$ significantly longer voiced transitions compared to $/ \mathrm{k} /(p<.001)$. 

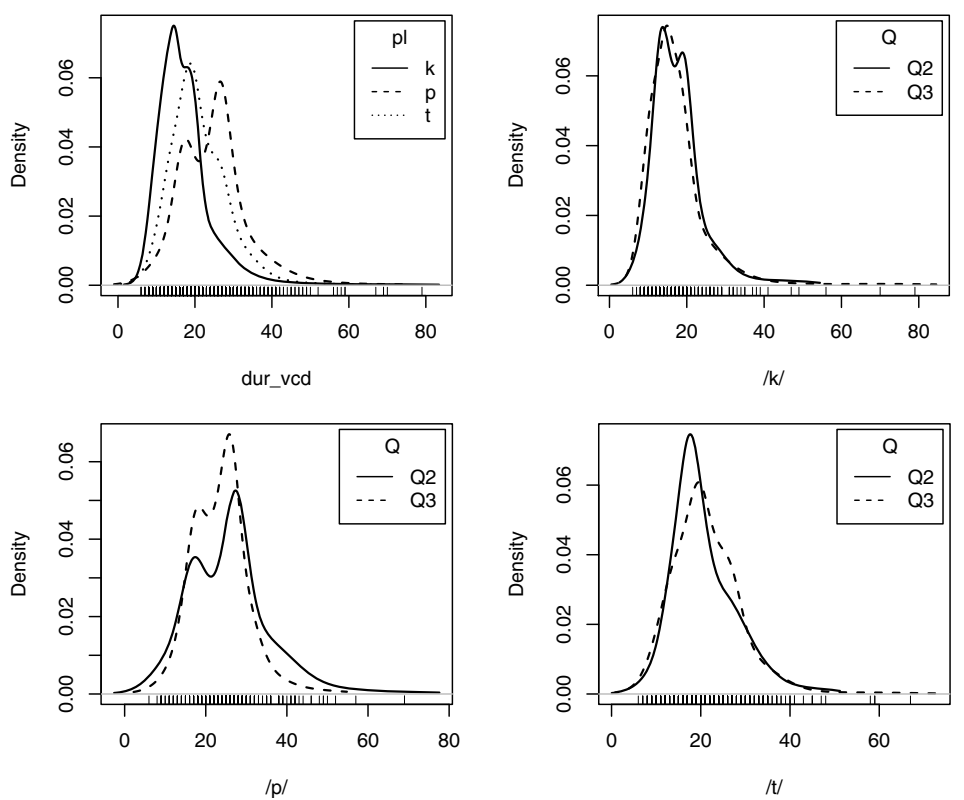

Figure 5. Density plots of duration of voiced transition.

The proportion of voiced transitions of the closure phase constituted, on average, over $20 \%$ in the case of Q2 and just below $20 \%$ in the case of Q3 (see Table 5). Proportions were close between all plosives in Q3; in Q2 the proportion differences were larger. The difference between proportion in voicing between plosives was significant $[F(2,1837)=37.14, p<.001]$. TukeyHSD confirmed the difference of voiced proportion between $/ \mathrm{p} /$ and other plosives ( $p<.001$ in both pairs); the difference between $/ \mathrm{k} /$ and $/ \mathrm{t} /$ was not significant. In Q2, the differences were even stronger than overall differences $[F(2,662)=16.64$, $p<.001]$; TukeyHSD confirmed the differences between all plosives (between $/ \mathrm{p} /$ and other plosives $p<.001, / \mathrm{k} /$ and $/ \mathrm{t} / p=.013$ ). In Q3, differences were significant $[F(2,1172)=7.33, p<.001)]$. TukeyHSD found significant difference between $/ \mathrm{k} /$ and $/ \mathrm{p} /(p<.001)$ and moderately significant difference between $/ \mathrm{k} /$ and $/ \mathrm{t} /(p=.038)$. The difference between $/ \mathrm{p} /$ and $/ \mathrm{t} / \mathrm{was}$ below significance level $(p=.070)$. 
Table 5. Mean proportion in percent of the voiced transition of the closure phase (median proportion given in parentheses).

\begin{tabular}{lccc}
\hline Plosive & Overall & Q2 & Q3 \\
\hline$/ \mathrm{k} /$ & $19(17)$ & $22(20)$ & $17(15)$ \\
$/ \mathrm{p} /$ & $23(21)$ & $27(24)$ & $18(17)$ \\
$/ \mathrm{t} /$ & $20(18)$ & $24(21)$ & $19(17)$ \\
\hline
\end{tabular}

For all plosives, the proportion of the voiced duration differed significantly between quantity degrees $[/ \mathrm{k} / F(1,326)=41.23, p<.001$; $/ \mathrm{t} / F(1,670)=39.14, p<.001 ; / \mathrm{p} / F(1,309)=40.44, p<.001]$.

In the model for proportion of the voiced transition, significant predictors were the plosive, the quantity degree, and the duration of the plosive token. The plosives $/ \mathrm{p} /$ and $/ \mathrm{t} / \mathrm{had}$ significantly higher proportions of voicing, compared to $/ \mathrm{k} /(p<.001)$; the proportion of voicing decreased in Q3 $(p=.001)$ and also decreased with the increase in duration of the token $(p<.001)$. In separate models for each plosive, for $/ \mathrm{k} /$ and $/ \mathrm{t} /$, a significant predictor was duration of the token $(/ \mathrm{k} / p<.001$, $/ \mathrm{t} / p=.020)$ and for $/ \mathrm{k} /$ also quantity $(p=.002) . / \mathrm{p} /$ had no significant predictors.

\section{Discussion}

\subsection{Durational variation}

Durations of the plosives roughly corresponded to those found in Türk (2018). Durations in Ariste (1933a) and Lehiste (1997) were longer; however, these may have been due to different speech styles.

Durational relations are similar to relations of single plosives, as described in Ermus (2017) and Ermus and Mihkla (2019). When excluding reduced allophones and comparing only voiceless and partlyvoiced allophones from Ermus (2017) to the present material, patterns are found to be slightly different between them. In the present study, we saw that the geminate $/ \mathrm{p} /$ is always the longest, while $/ \mathrm{k} /$ and $/ \mathrm{t} /$ are rather close in duration. In the case of single plosives, $/ \mathrm{p} /$ and $/ \mathrm{k} /$ were close in duration; /t/ was remarkably shorter. The biggest difference in durational patterns between geminates and single plosives was that, in the case of geminates, the tokens of partly-voiced allophones were 
shorter while, in the case of single plosives, tokens of partly-voiced allophone were longer than tokens of voiceless allophone.

Syllable structure was a significant factor influencing the duration of plosive tokens. Overall, durations were shorter after long vowels and diphthongs. These results are in accordance with results derived in Ariste (1933a) and Lehiste (1997) - although not in the same amount. In Lehiste's work, tokens following diphthongs stood out as the shortest ('ambiguously long' plosives).

\subsection{Burst and voicing}

Duration of burst was found to be almost solely dependent on the plosive. The plosive $/ \mathrm{k} /$ had the longest burst and $/ \mathrm{p} /$ and $/ \mathrm{t} /$, which is similar to singletons. Division of the burst durations was consistent with reports regarding other languages that have voiceless unaspirated category (Lisker and Abramson 1964 and Cho and Ladefoged 1999). There were moderately significant differences between quantity degrees in $/ \mathrm{k} /$ and $/ \mathrm{p} /$ but these rather suggest a tendency because differences are probably below the perception level.

Table 6. Mean burst durations of single plosives from previous studies.

\begin{tabular}{lccc}
\hline Studies & $/ \mathbf{k} /$ & $/ \mathbf{p} /$ & $/ \mathbf{t} /$ \\
\hline Ermus (2017) & 29 & 22 & 23 \\
Suomi and Meister (2012) & 19 & 13 & 16 \\
\hline
\end{tabular}

Regarding lenis and fortis opposition, it is interesting to compare the burst durations of geminate plosives to singletons. Table 6 presents the mean durations of burst of single plosives reported in Ermus (2017) and in Suomi and Meister (2012). Differences from geminates are rather small in Ermus (2017). If anything stands out, it is that burst phase seems to shorten with quantity. Results in Suomi and Meister (2012) diverge from the pattern, with shorter burst durations and smaller differences; still, the overall pattern is similar. The result is comparable with studies of the dialect Itunyoso Trique (Dicanio 2012) that found no significant differences between bursts or VOT between fortis and lenis plosives and, as well of Finnish (Doty et al. 2007), that found shorter 
VOT in geminate plosives compared to singletons. However, the results do not provide a reason for using lenis and fortis contrast in Estonian.

The plosive $/ \mathrm{p} /$ showed the largest amount of voicing and $/ \mathrm{k} /$ the smallest, in both the amount of partly voiced tokens and the duration of voiced transitions. Durations of voiced transitions varied greatly, but the mean durations were rather consistent; moreover, there were no big differences between quantity degrees. Proportion differences between two quantities were due to differences in overall durations of quantity degrees.

Although Estonian has no voicing contrast, the results confirm universal tendencies. It is more common in the world's languages for $/ \mathrm{k} /$ to occur voiceless and for $/ \mathrm{b} /$ to occur voiced, due to articulatory and aerodynamic reasons (Maddieson 2013). In studies of single plosives, $/ \mathrm{k} /$ has stood out with more extensive reduction than other plosives. Especially in spontaneous speech, / $\mathrm{k} /$ showed heavy voicing and reduction of burst, although this may be influenced by a large amount of short grammatical words containing $/ \mathrm{k} /$ in spontaneous speech. On the other hand, in read speech, it had the largest number of voiceless tokens as well (Ermus and Mihkla 2019). The pattern, in its own way, is logical from an articulatory standpoint. When the plosive is articulated loosely like in spontaneous speech, articulators do not reach their goal. The plosive strongly reduces and loses its characteristic burst; otherwise, it stays close to canonic voiceless form. The back of the tongue is slow and, at the same time, included in vowel articulation. Thus, when the durations are short, $/ \mathrm{k} /$ reduces considerably because there is insufficient time to form a closure. Duration of geminate is enough to produce complete gestures. The plosives $/ \mathrm{t} /$ and $/ \mathrm{p} /$ are articulated with more mobile parts of the mouth and are not influenced to the same degree.

No difference occurred between spoken and read speech. It may be that differences between two styles were also influenced by very different speech tempo of speakers in both styles. It is worth comparing controlled speech to spontaneous speech in the same speakers in the future.

\section{Conclusions}

The study observed durational realisation of Estonian geminate plosives and close-range factors influencing it. Research found that Estonian geminate plosives behave similarly to other languages with 
respect to overall duration and burst duration. Geminates behave similarly to singletons in Estonian, with minor differences that are probably influenced by articulatory reasons and different speech styles. Hypotheses on the influence of syllable structure were proved, but there was no firm support for proposed differences in burst duration between quantity degrees or between geminates and singletons.

The present study has investigated only a small amount of possible factors influencing the realisation of plosives. In the future, it would certainly be worth further studying the effects of vowel context and prosodic factors on durations and burst. It has been shown that vowel height can influence the duration of plosive tokens (Lippus and Šimko 2015) and VOT (Nearey and Rochet 1994). Suprasegmental features such as stress and phrase position might add to the adequate description of Estonian plosives.

\title{
Acknowledgements
}

This research has been supported by the Centre of Excellence in Estonian Studies (CEES, European Regional Development Fund) and is related to research project IUT35-1 (Estonian Research Council).

\author{
Address: \\ Liis Ermus \\ Institute of the Estonian Language \\ Roosikrantsi 6 \\ 10119 Tallinn, Estonia \\ E-mail: liis.ermus@eki.ee
}

\section{References}

Abramson, Arthur S. (1986) "The perception of word-initial consonant length: Pattani Malay". Journal of the International Phonetic Association 16, 1, 8-16. https://doi.org/10.1017/S0025100300003054

Ariste, Paul (1933a) "Eesti sulghäälikud k, p, t ja b, d, g". Eesti Keel 3, 73-82.

Ariste, Paul (1933b) "Eesti sulghäälikud k, p, t ja b, d, g”. Eesti Keel 6, 170-180.

Asu, Eva Liina, Pärtel Lippus, Karl Pajusalu, and Pire Teras (2016) Eesti keele hääldus.

(Eesti keele varamu, 2.) Tartu: Tartu Ülikooli Kirjastus. 
Asu, Eva Liina and Pire Teras (2009) "Estonian". Journal of the International Phonetic Association 39, 3, 367-372. https://doi.org/10.1017/S002510030999017X

Bates, Douglas, Martin Mächler, Ben Bolker, and Steve Walker (2015) "Fitting linear mixed-effects models using lme4". Journal of Statistical Software 67, 1, 1-48. https://doi.org/10.18637/jss.v067.i01

Boersma, Paul and David Weenink (2019) Praat: doing phonetics by computer [Computer program]. Available online at $<$ www.praat.org $>$. Accessed on 20.06.2019.

Butcher, Andrew (2004) “'Fortis/lenis' revisited one more time: the aerodynamics of some oral stop contrasts in three continents". Clinical Linguistics and Phonetics 18, 6-8, 547-557. https://doi.org/10.1080/02699200410001703565

Cho, Taehong, Sun-Ah Jun, and Peter Ladefoged (2002) "Acoustic and aerodynamic correlates of Korean stops and fricatives". Journal of Phonetics 30, 2, 193-228. https://doi.org/10.1006/jpho.2001.0153

Cho, Taehong and Peter Ladefoged (1999) "Variation and universals in VOT: evidence from 18 languages". Journal of Phonetics 27, 2, 207-229. https://doi.org/10.1006/jpho.1999.0094

Cho, Taehong, D. H. Whalen, and Gerard Docherty (2019) "Voice onset time and beyond: exploring laryngeal contrast in 19 languages". Journal of Phonetics 72, 52-65. https://doi.org/10.1016/j.wocn.2018.11.002

Dicanio, Christian T. (2012) "The phonetics of fortis and lenis consonants in Itunyoso Trique”. International Journal of American Linguistics 78, 2, 239-272. https://doi.org/10.1086/664481

Doty, Christopher S., Kaori Idemaru, and Susan G. Guion (2007) "Singleton and geminate stops in Finnish - acoustic correlates". Proceedings of Interspeech 2007, 2737-2740.

Eek, Arvo and Einar Meister (1996) "Eesti sõnaalguliste sulghäälikute akustika ja tajumine". Keel ja Kirjandus 3, 164-170.

Ermus, Liis (2017) "Eesti keele lühikeste klusiilide häälduse variatsioon ja seda mõjutavad tegurid". Mäetagused 68, 27-52. Available online at $<$ https://www.folklore.ee/tagused/nr68/ermus.pdf > . Accessed on 14.07.2019. https://doi.org/10.7592/MT2017.68.ermus

Ermus, Liis and Meelis Mihkla (2019) "Predictability of plosive reduction from written text in Estonian". In Sasha Calhoun, Paola Escudero, Marija Tabain, and Paul Warren, eds. Proceedings of the 19th International Congress of Phonetic Sciences, Melbourne, Australia 2019, 2635-2639. Canberra, Australia: Australasian Speech Science and Technology Association Inc.

Hansen, Benjamin B. and Scott Myers (2017) "The consonant length contrast in Persian: production and perception". Journal of the International Phonetic Association 47, 2, 183-205. https://doi.org/10.1017/S0025100316000244

Idemaru, Kaori and Susan G. Guion (2008) "Acoustic covariants of length contrast in Japanese stops". Journal of the International Phonetic Association 38, 2, 167-186. https://doi.org/10.1017/S0025100308003459

Kisler, Thomas, Uwe Reichel, and Florian Schiel (2017) "Multilingual processing of speech via web services". Computer Speech and Language 45, 326-347.

https://doi.org/10.1016/j.csl.2017.01.005 
Kraehenmann, Astrid (2001) "Swiss German stops: geminates all over the word". Phonology 18, 1, 109-145.

Kuzla, Claudia and Mirjam Ernestus (2011) "Prosodic conditioning of phonetic detail in German plosives". Journal of Phonetics 39, 2, 143-155. https://doi.org/10.1016/j.wocn.2011.01.001

Ladefoged, Peter (2001) Vowels and consonants: an introduction to the sounds of languages. Malden, Mass.: Blackwell.

Ladefoged, Peter and Keith Johnson (2010) A course in phonetics. Boston: Wadsworth Cengage Learning.

Ladefoged, Peter and Ian Maddieson (1996) The sounds of the world's languages. Oxford and Cambridge: Blackwell Publishers.

Lee, Hyun Bok (1993) "Korean”. Journal of the International Phonetic Association 23, 1, 28-31. https://doi.org/10.1017/S0025100300004758

Lehiste, Ilse (1997) "The structure of trisyllabic words". In Ilse Lehiste and Jaan Ross, eds. Estonian prosody: papers from a symposium, 149-164. Tallinn: Institute of Estonian Language.

Lippus, Pärtel (2018) Eesti keele spontaanse kõne foneetiline korpus v.1.0.4. Center of Estonian Language Resources. Available online at

$<$ https://metashare.ut.ee/repository/browse/bfadab5211a811e8a6e4005056b40024 b8e074be65ca4cbe9519b6d0d331bde3>. Accessed on 13.05.2019.

https://doi.org/10.15155/1-00-0000-0000-0000-00154L

Lippus, Pärtel and Juraj Šimko (2015) "Segmental context effects on temporal realization of Estonian quantity". Proceedings of the 18th International Congress of Phonetic Sciences (ICPhS 2015), [1-5].

Lisker, Leigh and Arthur S. Abramson (1964) "A cross-language study of voicing in initial stops: acoustical measurements". WORD 20, 3, 384-422. https://doi.org/10.1080/00437956.1964.11659830

Maddieson, Ian (2013) "Voicing and gaps in plosive systems". In Matthew S. Dryer and Martin Haspelmath, eds. The world atlas of language structures online. Leipzig: Max Planck Institute for Evolutionary Anthropology. Available online at $<$ https://wals.info/chapter/5>. Accessed at 27.06.2019.

Nearey, Terrance M. and Bernard L. Rochet (1994) "Effects of place of articulation and vowel context on VOT production and perception for French and English stops". Journal of the International Phonetic Association 24, 1, 1-18. https://doi.org/10.1017/S0025100300004965

Piits, Liisi (2016) Eesti Keele Instituudi kõnesünteesikorpus. Center of Estonian Language Resources. Available online at

$<$ https://metashare.ut.ee/repository/browse/d08d75c6a68611e6a6e4005056b400247c4ad19fbee24ef58cb1e725a915842d $>$. Accessed on 13.05.2019.

https://doi.org/10.15155/3-00-0000-0000-0000-05BDAL

R Core Team (2019) $R$ : a language and environment for statistical computing. Vienna, Austria: R Foundation for Statistical Computing. Available online at $<$ https://www.R-project.org/>. Accessed on 21.06.2019. 
Ridouane, Rachid (2014) “Tashlhiyt Berber”. Journal of the International Phonetic Association 44, 2, 207-221. https://doi.org/10.1017/S0025100313000388

Ridouane, Rachid and Pierre A. Hallé (2017) "Word-initial geminates: from production to perception". In Haruo Kubozono, ed. The phonetics and phonology of geminate consonants, 67-84. Oxford: Oxford University Press. https://doi.org/10.1093/oso/9780198754930.003.0004

Suomi, Kari and Einar Meister (2012) "A preliminary comparison of Estonian and Finnish plosives". Linguistica Uralica 3, 187-193. https://doi.org/10.3176/lu.2012.3.04

Türk, Helen (2018) "The three-way distinction of consonant duration in Estonian". Proceedings of the 9th International Conference on Speech Prosody 2018, 656-660. https://doi.org/10.21437/SpeechProsody.2018-2133

Wells, John (2015) SAMPA computer readable phonetic alphabet. Available online at $<$ http://www.phon.ucl.ac.uk/home/sampa/index.html>. Accessed on 12.06.2019.

Kokkuvõte. Liis Ermus: Eesti keele geminaatklusiilid: kestust puudutavaid tunnuseid. Eesti keele konsonandid esinevad kolmes vältes: lühike, pikk ja ülipikk. Sulghäälikuid on kirjeldatud ka leenise ja fortisena. Pikk ja ülipikk välde ning fortis vastavad geminaadile. Lühikeste sulghäälikute akustikat eesti keeles on korduvalt uuritud, kuid geminaatide kohta on esitatud vaid mõningast kestusinfot. Käesolev uurimus keskendus eesti keele geminaatsulghäälikute kestuses esinevatele korrapäradele ja nende võrdlusele lühikeste sulghäälikute kestusmustritega. Vaadeldi häälduskoha, välte, silbistruktuuri ja kõnestiili mõju häälikute üldkestusele, samuti vallandumisfaasi ja helilise algussiirde kestusele. Suurimad kestuserinevused olid tingitud välteerinevustest. Ilmnes mõningane silbistruktuuri mõju, mis oli kooskõlas eelnevate uurimustega. Kestusmustrid olid üldjoontes sarnased lühikeste sulghäälikute kestusmustritega, põhilised erinevused esinesid helilisuses. Vallandumisfaasi kestuses seevastu polnud võrreldes lühikeste häälikutega peaaegu mingeid erinevusi.

Märksõnad: eesti keel, geminaadid, sulghäälikud, kestus, seotud kõne, akustiline foneetika 